Ömer Halisdemir Üniversitesi İktisadi ve İdari Bilimler Fakültesi Dergisi

Yll: 2020 Cilt-Sayl: 13(2) ss: 227-241.

Academic Review of Economics and Administrative Sciences

Year: 2020 Vol-Issue: 13(2) pp: 227-241.

http://dergipark.org.tr/tr/pub/ohuiibf/

ISSN: 2564-6931

Araștırma Makalesi

DOI: 10.25287/ohuiibf.589519

Research Article

\title{
The Role Of Internal Control In Hotel Business: A RESEARCH ON FIVE-STAR HOTELS
}

\author{
Halil AKMESSE ${ }^{I}$ \\ Hilal G $\ddot{U} N D O \breve{G} A N^{2}$
}

\begin{abstract}
Today, the growth of enterprises and the more complexity of their activities bring up the need for an internal control system. Therefore, an effective internal control system must be established in hotel enterprises in order to minimize the risks that may arise. Based on this fact, the main purpose of this study is to determine the perceptions of hotel managers towards the internal control system and to examine the effects of dependent variable of "internal control system" on the independent variables of "segregation of duties", "protection of assets" and "verification of transactions". Additionally, the sub-objective of this study is to research the relationships between managers' perceptions of the internal control system and demographic characteristics. The research was carried out with the participation of 120 managers in five-star hotel enterprises operating in Alanya. The research data was collected through questionnaire technique. As a result of the research, there was no significant difference between the independent variables of "segregation of duties", "protection of assets" and "verification of transactions" and the internal control system perceptions of the managers. However, it was also concluded that managers' perceptions of the internal control system differed statistically according to their educational status.
\end{abstract}

Keywords : Internal Control, COSO Framework, Five-Star Hotels

Jel Codes $\quad$ : L83, M41, M42

\footnotetext{
${ }^{1}$ Assoc. Prof., Necmettin Erbakan University, Faculty of Tourism, Department of Tourism Administration, hakmese@konya.edu.tr, ORCID: 0000-0003-4694-2215.

${ }^{2}$ Lecturer, İstanbul Kültür University, Department of Tourism and Hotel Management, h.gundogan@iku.edu.tr, ORCID: 0000-0001-53957912.
} 


\section{İÇ KONTROLÜN OTEL İşLETMELERINDEKİ ROLÜ: BEŞ Yildizli Oteller ÜZERíne Bír ARAȘTiRMA}

\section{$\ddot{O} z$}

Günümüzde işletmelerin büyümesi ve faaliyetlerinin daha karmaşık hale gelmesi sonucunda ortaya çıkan bilgi edinme zorunluluğu gibi nedenler iç kontrol sistemine olan ihtiyacı gündeme getirmektedir. Dolaylsıyla oluşabilecek risklerin en aza indirebilmesi için otel işletmelerinde etkin iç kontrol sisteminin kurulması gerekmektedir. Bu noktada araştırmanın temel amacı, otel yöneticilerinin iç kontrol sistemine yönelik algılarını belirlemek ve "görev ayrımı", "varlıkların korunması" ve "işlemlerin doğrulanması" bă̆ımsız değişkenlerinin, "iç kontrol sistemi” bağımlı değişkeni üzerindeki etkisini incelemektir. Ayrıca araştırmada yöneticilerin iç kontrol sistemi alglları ile çeşitli demografik özellikleri arasındaki ilişkileri incelemek alt amaç olarak belirlenmiştir. Araştırma, Alanya Bölgesinde faaliyet gösteren beş ylldızlı otel işletmelerinde görevli olan 120 yöneticinin katılımı ile gerçekleştirilmiştir. Veriler anket tekniği aracılı̆̆ılla toplanmıştır. Araştırma sonucunda; "görevlerin ayrımı", "varlıkların korunması" ve "işlemlerin doğrulanması" bağımsız değişkenleri ile yöneticilerin iç kontrol sistemi algıları arasında anlamlı bir farklılık olmadı̆̆ tespit edilmiştir. Bununla birlikte yöneticilerin iç kontrol sistem algılarının eğitim durumuna göre istatistiksel açıdan anlamlı olarak farklılaştı̆̆ sonucu elde edilmiştir.

Anahtar Kelimeler

Jel Kodlart
: İ̧̧ kontrol, COSO Çerçevesi, Beş Yıldızlı Oteller

: L83, M41, M42

\section{INTRODUCTION}

Internal control systems are among the trending topics frequently discussed in the audit world. It is stated that internal control is related to risk management, especially in helping the business escape from bankruptcy. Furthermore, the internal control system is also important for the enterprises to continue to increase their profit and to help reduce the negative occasions (Kurniadi \& Zio, 2011: 1). In this respect, internal control refers to controls and balances used to prevent losses of a company and provide accurate financial reporting (Biegelman \& Bartow, 2006: 108). The well-designed and effective internal control helps to prevent and deter errors and irregularities (Davis et al., 2017: 60). Moreover, the internal control system in enterprises constitutes a basis for an effective accounting system. Hence, there is an increased interest in the internal control method (Ademola et al., 2015: 1094).

Enterprises are facing some problems that arise when they try to identify their strengths and assess their risks (Politis et al., 2009: 463). It is clearly known that hotel enterprises basically have a labor-intensive structure. It is also indicated that a certain amount of capital invested in this industry provides more jobs than the same amount of investment in other sectors (Kusluvan, 2003: 5). Since hotel enterprises are categorized under the services industry, the products offered in this industry are more specific than in other industries. Therefore, the management should be more careful about the implementation of internal control procedures in daily operations. Any incorrect operation in the hotel enterprise can directly affect the quality of the service offered to guests (Kurniadi \& Zio, 2011: 4). For this reason, it is an important task for hotel enterprises to provide a good service to their guests and to ensure its continuity.

In addition, high turnover rates and a lot of personnel working closely to the inventory items can cause the increased possibility of errors and cheating, because the operations in such enterprises are conducted by small units independent of each other. In this respect, hotel managers need to be well 
aware of the nature of internal control difficulties and the types of procedures that can be applied to manage these difficulties (Guilding, 2014: 91), since they are generally responsible for the establishment of an internal control system in enterprises.

It can be suggested that establishing an effective internal control is very important in hotel enterprises. Hence, the main objective of this study is to determine the perceptions of hotel managers towards the internal control system. Additionally, the sub-objective of this study is to research the relationships between managers' perceptions of the internal control system and demographic characteristics. In this research, the concept of the internal control system was firstly analyzed and the studies in the relevant literature were reviewed. Then, the research application in the five-star hotels operating in Alanya was conducted in order to determine the managers' perceptions of the internal control system, and the findings obtained from the analyzes were discussed.

\section{I.CONCEPTUAL FRAMEWORK}

Based on the literature review, there are many definitions about the internal control concept. Verschoor (1999: 408) defines internal control is a term used to describe how an entity provides its financial and other objectives. According to another definition internal control is as a process designed to provide reasonable assurance about the effectiveness of an entity's board of directors, management, and other employees' operations regarding keeping up with the goals about reporting and compliance (COSO, 2013: 2). Internal control help to rapid reporting and to prepare an efficient flow of documents and data (Frazer, 2016: 153). Therefore, it can be claimed that the internal control system includes all the controls within the enterprise (Daniela \& Atilla, 2013: 696).

Internal control also includes measures initiated to improve the reliability of the entity's accounting systems (Abdullahi \& Muturi, 2016: 764). According to Chong et al. (2018: 181), the basic principle of internal control is to control safety in an enterprise. For this reason, it can be suggested that there is a set of policies for internal control to ensure that an entity is properly processed to prevent waste and misuse of resources (Ejoh \& Ejom, 2014: 133). Internal control system ensures the enterprises to act more compatible with the laws and regulations. In addition to this, it plays a preventive role against losses caused by mistakes or fraud by monitoring and developing financial reporting processes (Rae \& Subramaniam, 2008: 105).

Internal control system is a necessity for enterprises. For instance, when preparing a financial report in an enterprise, an internal control system should be set up in order to comply with the law. In this way, the internal control system for enterprises can be considered as both a risk management system and a basic management system (Takahiro \& Jia, 2012: 66).

According to Marley and Pedersen (2009: 116), the general objectives of internal control are to protect the assets of the entity, control the accuracy of the accounting data and encourage adherence to the proposed management policies. The purpose of internal control is to prevent errors from occurring or to identify them. Otherwise, inconsistencies can lead to the destruction of the good reputation of the hotel business and to major financial problems. Sometimes problems can occur even in hotels with a well-established internal control system (Annaraud et al., 2014: 2017). A poorly-designed internal control system can lead to inefficiency, power abuse, and fraud which creates an environment of more potential (Peterson, 2018: 192).

Internal control has an important role in ensuring the continuity of the business objectives. In this sense, different models have been suggested for the proper implementation of internal control. One of the international internal control models used in the regulations on internal control and supervision in the literature is COSO (Dănescu et al., 2011: 340). Accordingly, the main objective of the Internal Control-Integrated Framework Report is to provide a framework for internal control among interested parties (Aldridge \& Colbert, 1994: 21). The COSO definition and model covering all elements of internal control system guide the other regulations (Owusu-Boateng et al., 2017: 3). The 
elements of internal control systems in the COSO framework include five components related to each other, including control environment, risk assessment, control activities, information and communication, and monitoring (Yang \& Guan, 2004: 551; Wardiwiyono, 2012: 344; Ayagre et al., 2014: 380). These components are as follows:

Control Environment: It forms the basis of all internal control system. It is the set of processes that constitute the basis for conducting internal control system across the organization. The establishment of the right control environment in the enterprise and the good coordination of the organization mean raising awareness of the managers and employees in the enterprise about the significance of the control (Yurniwatia \& Rizaldi, 2015: 846).

Risk Assessment: It is the basis for determining how to manage all risk levels. The precondition for risk assessment is the establishment of objectives related to risks. However, due to the nature and type of risks an enterprise will face, management determines the risk objectives of the organization in order to identify and analyze the possible risks to these objectives (Moeller, 2013: 60). Management is completely responsible for risk assessment. Therefore, management must ensure that risk management processes are in place and functional in order to achieve the specified business objectives (Ravaş, 2011: 218).

Control Activities: This component includes a set of activities such as "approval, authorization, reconciliations, business performance reviews, security of assets, and segregation of duties". Control activities, although the most visible element of internal control, are considered significant in preventing false actions (Abiola \& Oyewole, 2013: 43). Control activities are taken into consideration for management procedures designed to ensure the implementation and enforcement of policies and procedures. It also helps the management achieve its objectives and minimize risks (Trenerry, 1999: $14)$.

Information and Communication: Information systems enable the identification and timely communication of the appropriate information that allows the employees in the enterprise to fulfill their responsibilities and reach the business objectives (Choudhury \& Mitchell, 2013: 6). Therefore, it is necessary to ensure that this information is reliable and verifiable. Effective communication should be disseminated in the organization. The reason is that management and employees must have an effective internal communication system in both directions (Khosrowpour, 2001: 1048).

Monitoring: It refers to the activities designed to evaluate the effectiveness of internal control system in achieving the financial reporting targets of the entity (Aldridge \& Colbert, 1994: 22). Monitoring activities are carried out with the help of external auditors or internal audit unit. The execution of monitoring activities is continuously supervised. Deficiencies identified in the management report should also be communicated to the relevant units and individuals (Victor \& Linda, 2016: 41).

All components of internal control identified in the COSO report are required to establish and maintain a safe internal control system. Control activities of the system play an active role in strengthening the overall system. The weakness of any of the components will cause the entire internal control system to be adversely affected. Linking the chains together will enable the creation of an efficient control system of these components (Turner \& Weickgenannt, 2008: 100).

In many organizations, management must design an effective internal control system (Wahdan, 2018: 1). In addition, an appropriate accounting registry as well as an appropriate management control system is required in order to have a successful business (Sanusia et al., 2015: 158). According to the guidelines published on internal control by the Institute of Chartered Accountants in England and Wales (ICAEW), the management controls included among the internal control elements are periodically carried out by the senior management and include reviews of management accounts and comparisons with budgets (Monday et al., 2014: 241-242). Internal control improve the quality of information that helps managers make better decisions. In this respect, the reliability of information is very important for managers to make the right decisions. 
Like all businesses, hotel businesses are also affected by changes and developments. It is stated that hotel enterprises are at greater risk than those in other sectors because of their labor intensive structure. For this reason, an effective and well-designed internal control system that is regularly used will support the sustainability of management and prevent errors from occurring (Erkan et al., 2017: 136). When applying internal control system in such enterprises, the risks that will prevent the business from achieving its objectives should be handled both on the basis of divisions and in terms of the parties concerned. Hence, administrative controls and accounting controls deemed necessary to minimize these risks should be created (Aktürk, 2015: 112).

In the literature, there are previous studies conducted about the investigation of internal control system in the banking field (Tuan $\mathrm{Vu}, 2016$; Owusu-Boateng et al., 2017) in public institutions (Ademola, 2015; Aziz et al., 2015) and restaurant enterprises (Frazer, 2011: Kopotiienko, 2015). In addition, studies carried out within the scope of internal control system in the hotel businesses (Mihaela \& Mairan, 2013; Annaraud et al., 2014) are also available. Karagiorgos et al. (2011: 28-29) aimed to measure the effectiveness of internal supervision in Greek hotel enterprises. According to the results of the study, all dimensions of internal control systems were determined to be high, while the control environment component was rated to the highest. Kurniadi and Zio (2011: 62-63) examined the role of internal control system in the operations of international and local hotel businesses in Sweden and Indonesia. The study shows that the implementation of internal control system helps to ensure the effectiveness of the operations. It is also emphasized that the internal control system is a guide for the protection of assets, prevention of losses and the ability of enterprises to produce accurate and reliable financial reports. In the research conducted by Addey (2012: 68-69) about the evaluation and comparisons of internal control systems of two hotels located in Koforidua, it was concluded that control activities occured at all levels and functions of the enterprises. In the study conducted by Mndzebele (2013: 1-2) in hotel enterprises in the Zulwini valley, it was examined whether the use of Accounting Information Systems (AIS) improved the internal control systems in hotels. It was found out that there is a relationship between accounting information systems and internal control systems. It is additionally expressed that hotel management uses accounting information systems in internal control to provide more cost-effective and up-to-date information. Juen and Mustapha (2015: 409) also studied the effects of internal control practices on the performances of cheap hotels in Kuala Lumpur and Selangor in Malaysia. The findings of the study revealed that the control environment, information and communication and risk assessment elements are significantly related to the performance of the hotels. In the study carried out by Yemer and Chekol (2017: 29-31) in hotel enterprises in the cities of Bahir Dar and Gondar, Ethiopia, the relationship and effect of all components of internal control on hotel revenues were investigated. As a result of the study, it was determined that the components of internal control had a positive effect on the increase in hotel revenues. In particular, the components of control activities and information and communication were found to guide the estimation of hotel revenue.

As stated earlier, the objective of this study is to determine the perceptions of hotel managers regarding internal control and to examine the impact of independent variables such as "segregation of duties," "protection of assets," and "verification of transactions" on the dependent variable "internal control system". In addition, the sub-objective of this research is to the examine relationships between managers' perceptions of the internal control system and demographic characteristics. The reason for focusing on the internal control system and choosing the management departments in the hotel businesses in this research is that the establishment of an internal control system can minimize the negative effects of errors and deficiencies in hotel enterprises and the establishment and control of an effective internal control system belongs to the senior management. In addition, when the literature on the subject is examined, any study aimed at determining the internal control system perceptions of managers in hotel enterprises has not been accessed. Therefore, this is thought to reflect the authentic aspect of the study. In this respect, the hypotheses presented in the study are shown in Table 1.

\section{Table 1: Research Hypotheses}




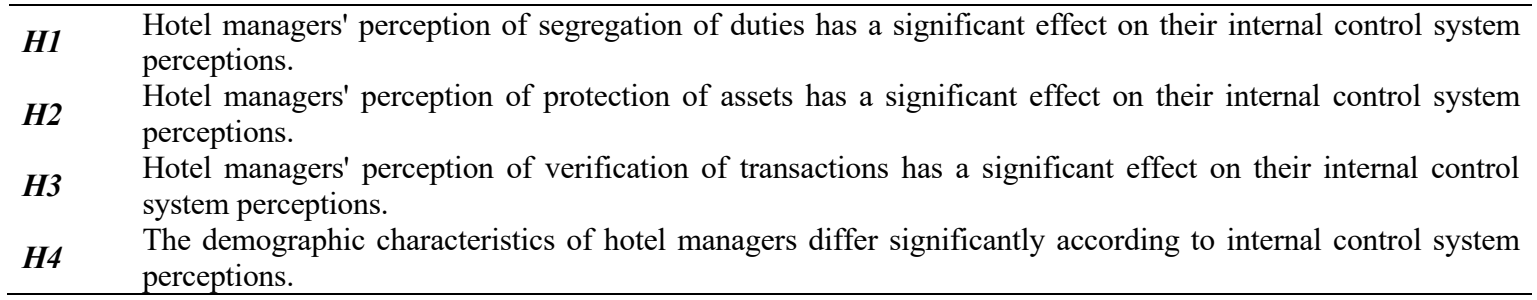

\section{METHODOLOGY}

The research universe consists of five star hotels in Alanya town of Antalya province. In order to determine the universe of the research, the number of five star hotel enterprises operating in the Alanya town was reached through the Antalya Directorate of Culture and Tourism. According to the latest statistical information accessed from the institution in, it was determined that a total of 73 fivestar hotel was active in Alanya. The number of individuals in the position of general manager and accounting manager in all these hotels, which also constitutes the research universe, has been found as 146. According to Altunışık et al. (2007: 127), the sample which can represent a homogeneous universe consisting of 146 individuals should involve at least 108 individuals. Thus, a total of 200 questionnaires were distributed to 73 five-star hotels which allowed to conduct research in the relevant season, however only 120 questionnaires from 66 hotels were returned. The research data was analyzed with SPSS 20.0 package software.

In this study, "homogeneous sampling" method was used. The homogeneous sampling method is the selection of individuals with defined qualifications to be included in the research (Ekiz, 2015: 105). The research data was collected by the questionnaire technique. As a data collection tool, the "demographic characteristics and personal characteristics form (item 5)", which aims to gather information about the demographic characteristics of the managers, and the Internal Control Survey Questionnaire (ICSQ) adapted by the researchers were used. The measurement of the 39-item scale was established in the Five-Point Likert system.

The scale used in this study was adapted from the $\mathrm{PhD}$ thesis prepared by Frazer (2011). The scale was tested for reliability and validity in terms of profit standards consistent with the COSO (1992) internal control integrated framework. It was observed that the items in the scale were categorized under one dimension of the scale as the dependent variable and the other three dimensions as independent variables, equaling to 4 dimensions in total. While "internal control" was determined as the dependent variable, the dimensions of "segregation of duties", "protection of assets", and "verification of transactions" were listed as independent variables.

\section{FINDINGS}

\section{I. Findings of Research Scale}

In this part of the study, findings related to the scale used in the research are discussed. The validity and reliability studies of the scale were conducted by the researchers. The items used in the study were analyzed by Cronbach Alpha reliability coefficient which is the most common reliability index. Cronbach Alpha is the average correlation between all items defined to measure the same items (Newman ve McNeil, 1998: 39). The overall reliability coefficient of the scale was determined to be 0.754 . As a result of the item analysis performed after the reliability analysis, no question was deduced from the scale as there was not any value that would significantly affect the reliability of the scale. After the reliability analysis, the scale was subjected to explanatory factor analysis. Accordingly, 
firstly KMO Bartlett's test was applied and the scale was tested whether or not it was suitable for factor analysis. As a result, it was indicated that the scale was suitable for factor analysis (KMO: ,525, Bartlett's test: $1863,646, \mathrm{p}=.000, \mathrm{p}<.05)$ and therefore it was subjected to Varimax rotation explanatory factor analysis. Based on the factor analysis, it was seen that some items in the scale were included in a meaningless whole except for the dimensions they were included in the original scale. At this point, the items (19 items) causing this occasion were removed from the scale and the factor analysis was repeated by placing four factor constraints. In this direction, the total variance explained as a result of the renewed analysis was determined as \%52,504. Moreover, it was observed that the expressions for measuring the same size of all items were combined with the highest values under the same dimension. Additionally, all items remaining in the scale as a result of factor analysis were subjected to reliability analysis again. According to the result of this new analysis, Cronbach's Alpha coefficient was determined to be 0.67 , and thus the remaining items were still very reliable. The results of the factor analysis and the reliability analysis applied to the overall scale are presented in Table 2 .

Table 2: Factor Analysis and Reliability Analysis Results Based on the Scale Developed in the Application

\begin{tabular}{|c|c|c|c|c|c|}
\hline \multirow{2}{*}{ ICSQ } & The Matrix of Rotated Items (Varimax) & \multicolumn{4}{|c|}{ Dimensions } \\
\hline & Items & 1 & 2 & 3 & 4 \\
\hline \multirow{3}{*}{ 焉 } & $\begin{array}{l}\text { Financial statements reflect the exact financial position of the hospitality } \\
\text { facility. }\end{array}$ &, 847 & & & \\
\hline & A financial audit is conducted on a yearly basis. & ,822 & & & \\
\hline & $\begin{array}{l}\text { Manuals and guidelines covering the up-to-date policies and procedures are } \\
\text { published. }\end{array}$ & ,403 & & & \\
\hline \multirow{5}{*}{ 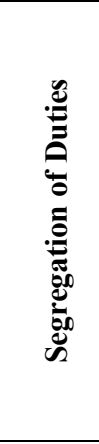 } & $\begin{array}{l}\text { Transactions regarding the counting of cash are controlled by more than one } \\
\text { person. }\end{array}$ & & 881 & & \\
\hline & $\begin{array}{l}\text { Cash transactions such as payments and bank reconciliations are prepared by } \\
\text { different employees other than those who keep the accounting records and } \\
\text { perform the cashier functions. }\end{array}$ & &, 880 & & \\
\hline & $\begin{array}{l}\text { Monthly bank reconciliations and checks are prepared by a different employee } \\
\text { than the one who prepares and approves them during the period. }\end{array}$ & &, 869 & & \\
\hline & $\begin{array}{l}\text { The people responsible for the cash control are rotated. (Constantly changing } \\
\text { their positions and preventing the same people from dealing with cash flow } \\
\text { processes). }\end{array}$ & & ,797 & & \\
\hline & $\begin{array}{l}\text { Cash checks and checks that provide value flow are signed by more than one } \\
\text { person. }\end{array}$ & & ,789 & & \\
\hline \multirow{6}{*}{ 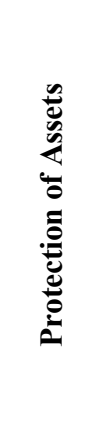 } & All blank checks and check stocks are accounted for and stored securely. & & & ,790 & \\
\hline & $\begin{array}{l}\text { All staff members (especially those handling cash and payments) are required to } \\
\text { take one full week of continuous vacation time annually to keep them out of the } \\
\text { system and whether cash flow processes or other processes are interrupted or if } \\
\text { there are discrepancies in accounts are identified. }\end{array}$ & & & ,759 & \\
\hline & All checks (including voided checks) are accounted for. & & & ,693 & \\
\hline & $\begin{array}{l}\text { The enterprise uses the Point of Sale System to monitor and control the sales, } \\
\text { purchases and inventory levels. }\end{array}$ & & & ,611 & \\
\hline & $\begin{array}{l}\text { Real assets related to inventories are shown in the balance sheet (Inventory on } \\
\text { hand reflects the inventory on balance sheet.) }\end{array}$ & & &, 547 & \\
\hline & The enterprise has a Point of Sale System. & & & ,374 & \\
\hline \multirow{5}{*}{ 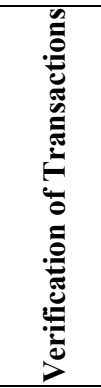 } & $\begin{array}{l}\text { Cash receipts are continuously recorded in the accounting system and they are } \\
\text { reconciled to the general ledger monthly. }\end{array}$ & & & & 691 \\
\hline & $\begin{array}{l}\text { Invoices from unfamiliar or unusual vendors are reviewed and approved for } \\
\text { payment by authorized personnel who are independent of the invoice processing } \\
\text { function. }\end{array}$ & & & & 661 \\
\hline & Necessary approvals are obtained from seniors before the purchase process. & & & & 624 \\
\hline & $\begin{array}{l}\text { Requests for reimbursement and refund invoices are checked for mathematical } \\
\text { accuracy and reasonableness are checked before approval. }\end{array}$ & & & & ,538 \\
\hline & $\begin{array}{l}\text { All purchases and requisitions of goods and services are reconciled to the } \\
\text { monthly general ledger. }\end{array}$ & & & &, 510 \\
\hline
\end{tabular}




\begin{tabular}{|l|l|c|c|} 
& $\begin{array}{l}\text { Unusual trends or discrepancies in enterprise accounts are identified and } \\
\text { reconciled monthly (weekly or every two weeks). }\end{array}$ & &, 504 \\
\hline & Total Variance Explained & $\mathbf{5 2 . 5 0 4}$ \\
\cline { 2 - 3 } & Total Reliability Coefficient (C. Alpha) & $\mathbf{. 6 7 0}$ \\
\hline
\end{tabular}

Dimensions from the scale after factor analysis and the mean and standard deviation values of these dimensions are presented in Table 3.

Table 3. The Mean and Standard Deviation Values of the Dimensions of the Scale

\begin{tabular}{lccc}
\hline Dimensions of Scale & $\mathbf{N}$ & $\overline{\mathbf{x}}$ & $\mathbf{s s}$ \\
Internal Control & 120 & 4,07 & 2,73 \\
Segregation of Duties & 120 & 4,09 & 2,79 \\
Protection of Assets & 120 & 4,09 & 1,90 \\
Verification of Transactions & 120 & 4,10 & 2,06 \\
Overall Average of the Scale & 120 & 4,09 & 1,26 \\
\hline
\end{tabular}

The items obtained for each dimension after the explanatory factor analysis with varimax rotation were named according to the intensity of the meanings they carry. The semantic content of each dimension presented in Table 3 is briefly explained.

As found as a result of the scale that;

Internal control: Ensures the reliability of financial reporting and regulations as well as the efficiency of enterprise.

Segregation of duties: Is related to assigning responsibilities to individuals to address issues such as authorization, keeping records and auditing.

Protection of assets: These activities protect the assets of the enterprise and ensure the reliability of accounting records. These activities also include the recording of transactions, physical controls, documents and records.

Verification of transactions: This verification facilitates the preparation of financial statements and accountability of assets.

As shown in Table 3, it was found out that mean of internal control scale was found to be $\overline{\mathbf{x}}=$ $4.09(\mathrm{ss}=1.26)$. The dimension of verification of transaction had the highest mean by $\overline{\mathbf{x}}=4.10(\mathrm{ss}=$ 2.06), while the dimension of internal control had the lowest mean by $\overline{\mathbf{X}}=4.07(\mathrm{ss}=2.73)$.

\section{II. Demographic Characteristics of Participants}

In this part of the study, demographic characteristics of the participants were presented. The frequency and percentages for the findings are given in Table 4.

Table 4: Demographic Characteristics of Participants

\begin{tabular}{lcc}
\hline Gender & f & $\mathbf{\%}$ \\
\hline Female & 8 & 6,7 \\
Male & 112 & 93,3
\end{tabular}




\begin{tabular}{lcc}
\hline Age & & \\
\hline $29-37$ & 3 & 2,5 \\
$38-46$ & 50 & 41,7 \\
$47-55$ & 53 & 44,2 \\
56 and over & 14 & 11,7 \\
\hline Education & & \\
\hline High School & 10 & 8,3 \\
Associate & 29 & 24,2 \\
Undergraduate & 79 & 65,8 \\
Graduate & 2 & 1,7 \\
\hline Position & & \\
\hline General Manager & 54 & 45,0 \\
Accounting Manager & 66 & 55,0 \\
\hline Job Experience & & \\
\hline Less than 1 year & 7 & 5,8 \\
1-5 years & 57 & 47,5 \\
6-10 years & 44 & 36,7 \\
11-15 years & 10 & 8,3 \\
16 years and over & 2 & 1,7 \\
\hline
\end{tabular}

When the demographic characteristics of the participants were examined, it is seen that 6.7 percent of them were female and 93.3 percent were male. The majority of the participants were in the $47-55$ age group by $44.2 \%$ and the second majority was in the $38-46$ age group by $41.7 \%$ and the remaining 29-37 age group was in the lowest group by $2.5 \%$. Regarding the educational status, $65.8 \%$ of them have an undergraduate level of education. In this respect, it can be said that the educational status of the participants is generally high. $55 \%$ of the participants were accounting managers and $45 \%$ of them were general managers and $46.7 \%$ of them had more than 5 years of experience in the company.

\section{III. Findings of Research Hypotheses}

Multiple regression analysis was applied to determine how the independent variables of "segregation of duties", "protection of assets" and "verification of transactions" of the H1, H2, and H3 hypotheses of the study predict the internal control system perceptions of the managers. The analysis results are presented in Table 5 .

Table 5: ICSQ Model Summary

\begin{tabular}{|c|c|c|c|c|}
\hline Model & $\mathbf{R}$ & $\mathbf{R}^{\mathbf{2}}$ & Adjusted $\mathbf{R}^{\mathbf{2}}$ & $\begin{array}{c}\text { Standard Error } \\
\text { of Estimate }\end{array}$ \\
\hline 1 & $, 145^{\text {a }}, 021$ &, 27453 \\
a. Predictors: (Constant), segregation of duties, protection of assets and verification of transactions &,- 004 \\
\hline
\end{tabular}

Multiple regression analysis can be expressed as an analysis to reveal the relationship between a dependent variable and a number of independent variables associated with it (Can, 2013: 247). As can be seen in Table 5, the independent variables of "segregation of duties", "protection of assets" and "verification of transactions" explain the variance of internal control perception at a rate of \%2.1 (R Square $=021$ ). In other words, the perception of internal control was described by these variables by $\%$ 2.1 
Table 6: ICSQ ANOVA Findings

\begin{tabular}{|c|c|c|c|c|c|c|}
\hline \multicolumn{2}{|r|}{ Model } & Sum of Squares & Sd & Mean Square & $\mathbf{F}$ & $\mathbf{p}$ \\
\hline \multirow{3}{*}{1} & Regression & 0,187 & 3 &, 062 & ,827 &, $482^{b}$ \\
\hline & Residual & 8,743 & 116 & 075 & & \\
\hline & Total & 8,93 & 119 & & & \\
\hline & a. Depende & rnal control & & & & \\
\hline & b. Predicto & egregation of dutie & tion $\mathrm{c}$ & verification of $t$ & & \\
\hline
\end{tabular}

According to ANOVA results presented in Table 6, it was found that there was no statistically significant relationship between the independent variables of "segregation of duties", "protection of assets" and "verification of transactions" and the perception of internal control ( $p>.05)$.

Table 7: ICSQ Coefficient Table

\begin{tabular}{|c|c|c|c|c|c|c|}
\hline & \multirow{2}{*}{ Model } & \multicolumn{2}{|c|}{ Unstandardized Coefficients } & \multirow{2}{*}{$\begin{array}{c}\begin{array}{c}\text { Standardized } \\
\text { Coefficients }\end{array} \\
\text { Beta }\end{array}$} & \multirow{2}{*}{$\mathbf{t}$} & \multirow{2}{*}{$\mathbf{p}$} \\
\hline & & B & $\begin{array}{c}\text { Standard } \\
\text { Error }\end{array}$ & & & \\
\hline \multirow{4}{*}{1} & (Constant) & 3,262 &, 773 & & 4,222 & 000 \\
\hline & Segregation of duties &, 025 & ,091 & 0,025 & 0,272 &, 786 \\
\hline & Protection of assets &,- 029 & 123 & $-0,022$ & $-0,24$ & 811 \\
\hline & $\begin{array}{l}\text { Verification of } \\
\text { transactions }\end{array}$ & ,202 &, 134 & 0,141 & 1,513 & , 133 \\
\hline
\end{tabular}

When the regression coefficients presented in Table 7 and the values of these coefficients at the $\mathrm{p}<.05$ significance level are examined, the level of relationship between the independent variables of the "segregation of duties", "protection of assets" and "verification of transactions" and the internal control system perceptions of the managers is insignificant ( $p>.05)$. In other words, it was inferred that the independent variables of "segregation of duties", "protection of assets" and "verification of transactions" are not a significant predictor of managers" perceptions of the internal control system. The results obtained in this direction indicate that $\mathrm{H} 1, \mathrm{H} 2$ and $\mathrm{H} 3$ hypotheses are not supported.

The research data was subjected to normal distribution analysis with Kolmogorov-Smirnov method and it was understood that the data set did not show normal distribution. For this reason, nonparametric test methods were used to test hypotheses. To test the H4 hypothesis, Mann Whitney-U test was used for the comparison of the two groups and Kruskal-Wallis H test was used for the comparison of more than two groups. Only statistically significant results were presented in the analysis. The results of the Kruskal-Wallis $T$ test are presented in Table 8 which was conducted to examine the relationship between internal control system perceptions and educational status of managers.

Table 8: Kruskal-Wallis H Test Results by Educational Status Variable

\begin{tabular}{lllcccc}
\hline ICSQ & Educational Status & N & Mean Rank & Sd & $\mathbf{X}^{\mathbf{2}}$ & $\mathbf{p}$ \\
\hline \multirow{3}{*}{ Internal Control } & High School & 10 & 67,7 & & & 337 \\
& Associate & 29 & 66,83 & 3 & 3,381 &, 337 \\
& Undergraduate & 79 & 57,46 & & & \\
\hline
\end{tabular}




\begin{tabular}{|c|c|c|c|c|c|c|}
\hline & \multirow[b]{2}{*}{ Graduate } & \multirow[b]{2}{*}{2} & \multirow[b]{2}{*}{53} & & \\
\hline & & & & \multirow{5}{*}{3} & & \\
\hline \multirow{4}{*}{$\begin{array}{l}\text { Segregation of } \\
\text { Duties }\end{array}$} & High School & 10 & 57,4 & & \multirow{4}{*}{2,041} & \multirow{4}{*}{,564 } \\
\hline & Associate & 29 & 64,93 & & & \\
\hline & Undergraduate & 79 & 58,85 & & & \\
\hline & Graduate & 2 & 77 & & & \\
\hline \multirow{4}{*}{$\begin{array}{l}\text { Protection of } \\
\text { Assets }\end{array}$} & High School & 10 & 77,8 & \multirow{4}{*}{3} & \multirow{4}{*}{10,881} & \multirow{4}{*}{, 012} \\
\hline & Associate & 29 & 53,69 & & & \\
\hline & Undergraduate & 79 & 59,37 & & & \\
\hline & Graduate & 2 & 117,25 & & & \\
\hline \multirow{4}{*}{$\begin{array}{l}\text { Verification of } \\
\text { Transactions }\end{array}$} & High School & 10 & 58,95 & \multirow{4}{*}{3} & \multirow{4}{*}{6,094} & \multirow{4}{*}{, 107 } \\
\hline & Associate & 29 & 64,66 & & & \\
\hline & Undergraduate & 79 & 57,93 & & & \\
\hline & Graduate & 2 & 109,5 & & & \\
\hline
\end{tabular}

*The difference is significant at $\mathrm{p}<.05$ level.

As seen in Table 8, there was a significant difference between the educational status of the managers and the protection of the assets as a result of the Kruskal-Wallis $\mathrm{H}$ test analysis $\left[\mathrm{X}^{2}(3)=10,881 ; \mathrm{p}=.012 ; \mathrm{p}<.05\right]$. After the multiple comparisons with the Mann-Whitney U test, this difference was determined between high school-associate degree groups, high school-graduate groups and undergraduate-graduate groups. However, there was no statistically significant difference between the education status of the managers and the dimensions of internal control $\left[X^{2}(3)=3,381, p>.05\right]$, segregation of duties $\left[X^{2}(3)=2,041, p>.05\right]$, and verification of transactions $\left[X^{2}(3)=6,094, p>.05\right]$.

\section{CONCLUSION AND RECOMMENDATIONS}

In this study, empirical information was presented on the determination of internal control perceptions of managers in five-star hotels in Alanya. When the mean scores of the managers on the internal control survey form were examined, it was observed that the total mean score was high. However, it was determined that the dimension of verification of transactions had the highest mean score, while the dimension of internal control had the lowest mean score. This result indicates that the managers are highly skilled in the preparation of financial statements, but they are not equally successful in ensuring the reliability of financial reporting and improving the efficiency of the business. In addition, the fact that all mean scores are close to one another and the total mean score is high implies that managers' perceptions of internal control are at a high level. The study conducted by Karagiorgos et al. (2011: 28-29) in Greek hotel enterprises supports this finding of this research with regards to the determination of all elements of the internal control system are in higher orders. However, when the different studies carried out in hotel enterprises in the literature (Kurniadi \& Zio, 2011; Addey, 2012; Mndzebele, 2013; Yemer \& Chekol, 2017) were examined, it was determined that the internet control system had a positive effect on the realization of their targets and also on increasing their revenues.

As a result of the analysis of the hypotheses of the study, it was found that the level of relationship between the perceptions of segregation of duties and internal control system of hotel managers is meaningless. Marley and Pedersen (2009: 116) states that the assignment of responsibilities such as authorization and supervision to managers on the segregation of duties is decisive on the internal control system. Furthermore, it was found out that there was no statistically significant relationship between hotel managers' perceptions of the protection of assets and the internal control system. In the literature (Frazer, 2011; Frazer, 2016), it is suggested that the protection of assets of the business and ensuring the reliability of the accounting records are beneficial in terms of internal control. Finally, it was concluded that the perception of hotel managers' verification of 
transactions did not have a significant effect on their perceptions of the internal control system. However, the verification of transactions is considered significant for establishing effective internal control in the business as it ensures the preparation of financial statements. When the relationships between the demographic characteristics of the managers and the internal control system perceptions were examined, it was determined that there was a significant difference between the educational status and internal control system perceptions. After the multiple comparisons with the Mann-Whitney $\mathrm{U}$ test, this difference was identified between high school-associate degree groups, high schoolgraduate groups and undergraduate-graduate groups. In addition, there was no statistically significant difference between the managers' gender, age, position/title, job experience and their perceptions of the internal control system $(p>.05)$. It can be stated considering the gender factor that this is due to the limited number of female managers that can influence statistical analysis at a misleading level. In addition, in terms of the scope of the study, the similar nature of the information of the managers in the relevant department suggests that there is no significant difference. The fact that the job experience in the business is primarily concentrated in five years and less suggests that the experience of the managers in the business is not decisive in the relationship between the perceptions of the internal control system.

Some limitations were placed regarding carrying out this research in hotel businesses. The main reason for this is to ensure that data is obtained more quickly and correctly. Therefore, the objective of the research was limited to identifying the managers' perceptions of the internal control system of hotel enterprises operating in Alanya. It was also assumed that the managers who participated in the research correctly perceived the expressions in the scale.

In accordance with the results obtained, it is understood that the internal control dimension on the scale used to collect data in the study has a lower level of mean compared to other dimensions. In this case, it can be said that an organization chart should be created which clearly describes the areas of business authority and responsibility. This is especially important in terms of the job descriptions of the employees, because the opinions of the employees about the procedures in the organizational chart can lead to the emergence of innovative ideas related to the internal control system. With the use of new technology systems, the internal control system could be updated. The elimination of bureaucracy in the enterprise, the more efficient use of computerized systems, accounting procedures and policies in accordance with a well-defined organizational structure can also be created. It can also be said that rotation applications are important in terms of increasing the effectiveness of the internal control system. It is important to establish monitoring processes in order to minimize the negative impacts of errors and fraud in the enterprise. Thus, the efficiency of the internal control system can be further increased by recording and monitoring all operations in the organization. Moreover, it is a must that more attention should be paid to internal control issues to ensure efficiency of the activities in the enterprise. The fact that the hotel management prepares detailed and up-to-date documentation about the company's policies and procedures suggests that it will help solve some of the internal control systems in the enterprise. This research was carried out only in five-star hotels in Alanya, therefore it is estimated that the studies to be conducted in different areas of the industry will reveal different findings.

\section{REFERENCES}

Abdullahi, M.H. \& Muturi, W. (2016). Effect of Internal Control Systems on Financial Performance of Higher Education Institutions in Puntland, International Journal of Economics, Commerce and Management United Kingdom, IV(12), 762-780. 
Abiola, I. \& Oyewole, A.T. (2013). Internal Control System on Fraud Detection: Nigeria Experience, Journal of Accounting and Finance, 13(5),141-152.

Addey, J.N.A. (2012). An Assessment of Internal Control System on the Image of the Hospitality Industries in Royal Mac-Dic Hotel and Capital View Hotels. Unpublished Master's Thesis. Kwame Nkrumah University of Science and Technology, Kumasi, Ghana.

Ademola, I.S., Adedoyin, A.O. \& Alade, O.R. (2015). Effect of Internal Control System in Nigeria Public Sectors: A Case Study Of Nigeria National Petroleum Corporation, International Journal of Economics, Commerce and Management, III(6), 1093-1105.

Aktürk, A. (2015). Konaklama İşletmelerinde Etkin Bir İç Kontrol Sisteminin Tesisi Bağlamında Muhasebe Sistem Organizasyonu: Bir Vaka Analizi, Journal of Accounting, Finance and Auditing Studies, 1(4), 108-127.

Aldridge, R. \& Colbert, J. (1994). Management's Report on Internal Control, and the Accountant's Response, Managerial Auditing Journal, 9(7), 21-28.

Altunışık, R., Çoşkun, R., Bayraktaroğlu, S. \& Yıldırım, E. (2007). Sosyal Bilimlerde Araştırma Yöntemleri SPPS Uygulamalı. İstanbul: Sakarya Publishing.

Annaraud, K., Singh, D. \& Lively, H. (2014). Assessing and Analyzing Internal Control Practices in the Lodging Industry. The Journal of Hospitality Financial Management, 22, 26-31.

Ayagre, P., Appiah-Gyamerah, I. \& Nartey, J. (2014). The effectiveness of Internal Control Systems of Banks: The case of Ghanaian banks. International Journal of Accounting and Financial Reporting, 4(2), 377389.

Aziz, M.A.A., Said, J. \& Alam, M.M. (2015). Assessment of the Practices of Internal Control System in the Public Sectors of Malaysia. Asia-Pacific Management Accounting Journal, 10(1), 43-62.

Biegelman, M.T. \& Bartow, J.T. (2006). Executive Roadmap to Fraud Prevention and Internal Control: Creating a Culture of Compliance. New Jersey: Wiley.

Can, A. (2013). SPPS ile Bilimsel Araştırma Sürecinde Nicel Veri Analizi. Ankara: Pegem Akademi Publishing.

Chong, H.C., Ramayah, T. \& Subramaniam, C. (2018), The Relationship Between Critical Success Factors, Internal Control and Safety Performance in the Malaysian Manufacturing Sector. Safety Science, 104, 179-188.

Choudhury, F. \& Mitchell, P. (2013). COSO in the Worlbank, Margaret E. Van Biene-Hershey, Leon A.M. Strous (Eds.), Integrity and Internal Control in Information Systems, in Strategic Views on the Need for Control, Amsterdam: Springer Science Business Media LLC.

COSO. The 2013 COSO Framework \& SOX Compliance, June.

Dănescu, T., Prozan, M. \& Dănescu, A.C. (2011). Internal Control Activities: Cause and Effect of a Good Governance of Accounting Reportings and Fiscal Declarations. Annales Universitatis Apulensis Series Oeconomica, 13(2), 339-349.

Daniela, P. \& Atilla, T. (2013). Internal Audit Versus Internal Control and Coaching. Procedia Economics and Finance, 6, 694-702.

Davis, J.T., Ramamoorti,S. \& Krull, G,W. (2017). Monitoring Internal Control Systems: A Case and Spreadsheet Based Pedagogical Approach. Educator Journal, 12(1), 59-68.

Ejoh, N. \& Ejom, P. (2014). The Impact of Internal Control Activities on Financial Performance of Tertiary Institutions in Nigeria. Journal of Economics and Sustainable Development, 5(16),133-143.

Ekiz, D. (2015). Bilimsel Araştırma Yöntemleri. (4. Edition). Ankara: Anı Publishing.

Erkan, M., Okutmuş E. \& Ergül A. (2017). The Internal Control System in the Prevention of Mistakes and Fraud: An Application in Hospitality Management. Kıymet Çalıyurt \& Ülkü Yüksel (Eds.), in Sustainability and Management: An International Perspective, New York: Routledge.

Frazer, L. (2011). The Effect of Internal Control on the Operating Activities of Small Restaurants. Unpublished $\mathrm{PhD}$ Theses. Walden University College of Management and Technology, Minneapolis, USA.

Frazer, L. (2016). Internal Control: Is it a Benefit or Fad to Small Companies? A Literature Dependency Perspective. Journal of Accounting and Finance, 16(4),149-161.

Guilding, C. (2014). Accounting Essentials for Hospitality Managers. (Third Edition). New York: Routledge. 
Juen, C.S. \& Mustapha, M. (2015). An Assessment of Internal Controls in Budget Hotels in Malaysia, Proceedings of the International Conference on Natural Resources. Tourism and Services Management 2015, Sabah, Malaysia, 14-16 April.

Karagiorgos, T., Drogalas, G. \& Giovanis, N. (2011). Evaluation of the Effectiveness of Internal Audit in Greek Hotel Business. International Journal of Economic Sciences and Applied Research, 4(1), 19-34.

Khosrowpour, M. (2001). Managing Information Technology in a Global Economy. London: Idea Group Publishing.

Kopotiienko, T. (2015). Internal Audit of the Operating Costs of Restaurant Enterprises. Herald Of Knute, 6, 127-136.

Kusluvan, S. (2003). Characteristics of Employment and Human Resource Management in the Tourism and Hospitality Industry, S. Kusluvan (Ed.). In Managing Employee Attitudes and Behaviors in the Tourism and Hospitality Industry, New York: Nova Science Publishers.

Kurniadi, L. \& Zio, L. (2011). The Role of Internal Control in the Operation of Hotels, BUSP03 Degree Project, 15 ECTS Master Thesis in Accounting and Auditing, Lund, Sweden, 31 May.

Marley, S. \& Pedersen, J. (2009). Accounting for Business: An Introduction. (Second Edition). Australia: Pearson Education.

Mihaela, D. \& Mairan, T. (2013). Internal Control Organization in Accomodation Units. Lucrări Ştiinţifice Facultatea de Management Agricol, 1(4), 86-92.

Mndzebele, N. (2013). The Usage of Accounting Information Systems for Effective Internal Controls in the Hotels, International Journal of Advanced Computer Technology, 2(5), 1-3.

Moeller, R.R. (2013). Executive's Guide to COSO Internal Controls: Understanding and Implementing the New Framework. New Jersey: WILEY.

Monday, J.U., Inneh, G.E. \& Ojo, V.O. (2014). Internal Controls and Operatıng Performance of Small Businesses in Lagos Metropolis, International Conference on Accounting. Finance and Management, 9(11), 237-256.

Newman, N. \& McNeil, K. (1998). Conducting Survey Research in the Social Sciences. New York: University Press of America.

Owusu-Boateng, W., Amofa, R. \& Owusu, I.O. (2017). The Internal Control Systems of GN Bank Ghana. British Journal of Economics, Management \& Trade, 17(1), 1-17.

Peterson, A.N. (2018). Differences in Internal Control Weaknesses Among Varying Municipal Election Policies. Journal of Accounting and Public Policy, 37(3), 191-206.

Politis, Y., Litos, C., Grigoroudis, E. \& Moustakis, V.S. (2009). A Business Excellence Model for the Hotel Sector: Implementation to High-Class Greek Hotels. Benchmarking: An International Journal, 16(4): 462-483.

Rae, K. \& Subramaniam, N. (2008). Quality of Internal Control Procedures Antecedents and Moderating Effect on Organisational Justice and Employee Fraud. Managerial Auditing Journal, 23(2), 104-124.

Ravaş, B. (2011). The Role of the Internal Audit in the Tourism Unit's Risk Management Process. Annals of the University of Petroşani. Economics, 11(1): 215-222.

Sanusia, Z.M., Joharib, R.J Saida, J. \& Iskandara, T. (2015). The Effects of Internal Control System, Financial Management and Accountability of NPOs: The Perspective of Mosques in Malaysia. Procedia Economics and Finance, 28, 156-162.

Takahiro, S. \& Jia, P. (2012), Comparison of Internal Control Systems in Japan and China. International Journal of Business Administration, 3(1), 66-75.

Trenerry, A. (1999). Principles of Internal Control. Hong Kong: UNSW Press.

Tuan Vu, H. (2016). The Research of Factors Affecting the Effectiveness of Internal Control Systems in Commercial Banks-Empirical Evidence in Viet Nam. International Business Research, 9(7), 144-153.

Turner, L. \& Weickgenannt, A.B. (2008). Accounting Information Systems: Controls and Processes. New Jersey: Wiley.

Verschoor, C.C. (1999). Corporate Performance Is Closely Linked to a Strong Ethical Commitment, Business and Society Review, 104(4), 407-415. 
Victor, D.I \& Linda, E.N. (2016). Internal Control Techniques and Fraud Mitigation in Nigerian Banks. IOSR Journal of Economics and Finance, 7(5), 37-46.

Wahdan, M.A. (2018). Impact of a Practical Flowcharts Approach on Educating the Control Risk Assessment, Accounting and Finance Research, 7(2), 1-18.

Wardiwiyono, S. (2012). Internal Control System for Islamic Micro Financing: An Exploratory Study of Baitul Maal Wat Tamwil in the City of Yogyakarta Indonesia. International Journal of Islamic and Middle Eastern Finance and Management, 5(4), 340-352.

Yang, D.C. \& Guan, L. (2004). The Evolution of IT Auditing and Internal Control Standards in Financial Statement Audits The case of the United States. Managerial Auditing Journal, 19(4), 544-555.

Yemer M. \& Chekol F. (2017). The Effect of Internal Controls Systems on Hotels Revenue. A Case of Hotels in Bahir Dar and Gondar Cities. Arabian Journal of Business and Management Review, 6(6), $19-37$.

Yurniwatia \& Rizaldi, A. (2015). Control Environment Analysis at Government Internal Control System: Indonesia Case. Social and Behavioral Sciences, 211, 844-850. 